\title{
Environmental and climatic factors affecting winter hypoxia in a freshwater lake: evidence for a hypoxia refuge and for re-oxygenation prior to spring ice loss
}

\author{
Michael N. Davis • Thomas E. McMahon (i) Kyle A. Cutting • Matthew E. Jaeger
}

Received: 26 March 2020/Revised: 7 July 2020/Accepted: 10 August 2020/Published online: 7 September 2020

(C) The Author(s) 2020

\begin{abstract}
Low dissolved oxygen, or hypoxia, is a common phenomenon in ice-covered lakes in winter. We measured dissolved oxygen (DO) before, during, and after ice-over to characterize the timing, severity, and spatial variability of winter hypoxia in Upper Red Rock Lake, Montana, home to one of the last remaining lacustrine populations of endemic Montana Arctic Grayling (Thymallus arcticus). Unlike most previous investigations of winterkill-prone lakes, we observed considerable horizontal spatial variability in DO, a non-linear winter oxygen depletion rate, and lake-wide re-oxygenation 2-4 weeks prior to spring
\end{abstract}

Handling editor: Pauliina Louhi

M. N. Davis · T. E. McMahon

Fish and Wildlife Ecology and Management Program,

Ecology Department, Montana State University,

Post Office Box 173460, Bozeman, MT 59717, USA

Present Address:

M. N. Davis $(\square)$

American Rivers, 2150 Allston Way, Suite 320, Berkeley, CA 94704, USA

e-mail: mike.n.davis@gmail.com

K. A. Cutting

U.S. Fish and Wildlife Service, Red Rock Lakes National Wildlife Refuge, 27650B South Valley Road, Lima, MT 59739, USA

\section{E. Jaeger}

Montana Department of Fish, Wildlife and Parks, 730 1/2

North Montana Road, Dillon, MT 59725, USA ice loss. Parts of the upper $1 \mathrm{~m}$ of the lake and near stream mouths remained well-oxygenated even during late winter. DO levels were strongly associated with maximum daily air temperature. Our analysis of a 28-year weather record revealed large interannual variability in risk of winter hypoxia, with a slight declining trend in winter severity (number of days with maximum air temperatures $\leq 0^{\circ} \mathrm{C}$ ) in Upper Red Rock Lake. The approach we used in our study provides a useful framework for quantifying and mapping the seasonal dynamics of the extent and severity of winter hypoxia, and for identifying critical winter habitats.

Keywords Winter $\cdot$ Hypoxia $\cdot$ Grayling

\section{Introduction}

Low dissolved oxygen $(D O)$, or hypoxia, is a common and widespread phenomenon in ice-covered lakes in winter (Greenbank, 1945; Agbeti \& Smol, 1995; Hasler et al., 2009). The onset of ice cover begins a period of physical separation of water and the atmosphere, which slows or halts processes that replenish DO. Ice and snow cover prevents oxygenation of lake water by diffusion and aeration, slows convective mixing, and reduces the amount of light available for photosynthetic production of oxygen by 
algae and submerged vegetation (Welch \& Kalff, 1974; Malm et al., 1998; Terzhevik et al., 2009). If ice cover persists for a sufficient duration, the consumption of oxygen by microbial decomposition of dead and decaying organic matter and by absorption from bottom sediments may deplete DO to the point of hypoxia. In contrast, photosynthesis and DO production may continue to occur if light can still penetrate ice and snow cover. In most instances, the winter oxygen-limiting period ends with the breakup of lake ice in spring (Barica \& Mathias, 1979).

Hypoxia can be a major cause of winter mortality in fishes (Greenbank, 1945; Cooper \& Washburn, 1949; Hughes, 1973), which can limit species abundance and persistence (Danylchuk \& Tonn, 2003) and fish assemblage composition (Tonn \& Magnuson, 1982). The degree of winter hypoxia in ice-covered lakes is largely a function of pre-ice total oxygen storage, lake morphology, water exchange rate, duration of ice cover, extent of under-ice photosynthesis, and presence of inlet streams (Greenbank, 1945; Mathias \& Barica, 1980; Guenther \& Hubert, 1991; Leppi et al., 2016). Winter hypoxia is common in shallow, eutrophic lakes with high rates of winter oxygen depletion (Barica \& Mathias, 1979; Mathias \& Barica, 1980; Babin \& Prepas, 1985; Terzhevik et al., 2009). Annual variability in winter air temperature and snowfall, however, may also have a significant effect on hypoxia development by influencing duration of the ice-cover period and depth of surface snow accumulation, which limits light penetration thereby reducing photosynthetic production of oxygen by algae and submerged aquatic vegetation (Barica \& Mathias, 1979; Baehr \& DeGrandpre, 2002).

Knowledge of the factors that contribute to the development of winter hypoxia allow for the identification of lakes at risk for winterkill and for the application of predictive models of winter DO concentration (Barica \& Mathias, 1979; Fang \& Stefan, 2000, White et al., 2008; Leppi et al., 2016). The ability to predict whether a lake is at risk of severe winter hypoxia is an important management tool allowing preemptive action to avert large-scale winterkill of important fishery resources (Barica \& Mathias, 1979; Barica et al., 1983; Prowse \& Stephenson, 1986). Many predictive models of whole-lake DO conditions rely on lake morphometric parameters to predict DO concentrations and the likelihood of winterkill (Barica \& Mathias, 1979;
White et al., 2008; Leppi et al., 2016). Some winterkill risk models have incorporated weather conditions and landscape-level variables, in addition to the aforementioned lake attributes, to predict winter hypoxia severity (Fang \& Stefan, 2000). To date, winter hypoxia models have generally relied on DO sampling from a single site to characterize whole-lake hypoxia severity in small lakes with limited surface inflow. However, the extent of winter hypoxia may be more heterogeneous, especially in larger lakes with surface inflow, requiring more extensive sampling to accurately characterize the spatial and temporal extent of hypoxia (Guenther \& Hubert, 1991; Baehr \& DeGrandpre, 2002; Hasler et al., 2009).

Our study focused on Upper Red Rock Lake, Montana, a shallow, eutrophic, high-elevation lake with high potential for development of hypoxia during winter ice cover (Gangloff, 1996). The lake is also home to Montana Arctic grayling (Thymallus arcticus), a now rare, glacial relict population confined to the Upper Missouri River watershed, and which occupy only a small fraction of their historic range (Liknes \& Gould, 1987; Kaya, 1992). The population in Upper Red Rock Lake is the only significant remaining native, lacustrine population (Nelson, 1954; Kaya, 1992; Rens \& Magee, 2007), and is genetically distinct from other Arctic grayling in Montana and from populations further north in Canada, and is in extremely low numbers $(<300$ spawners) (Peterson \& Ardren, 2009; Warren et al., 2020). In a previous investigation, Gangloff (1996) observed widespread hypoxia in the lake, including evidence of fish mortality under the ice. Low overwinter survival due to winter hypoxia has been hypothesized as a limiting factor for this important population (Vincent, 1962; Gangloff, 1996; Mogen, 1996; Warren \& Jaeger, 2017; Warren et al., 2020). However, Gangloff (1996) reported that hypoxia extent varies considerably due to annual fluctuations in environmental and weather conditions, and that inlet stream mouths may provide refugia from hypoxic conditions. However, the spatial extent and dynamics of winter hypoxia is not well known for this system. The objectives of this study were to assess the winter hypoxia threat in Upper Red Rock Lake by (1) determining the timing, severity, and spatial variability of winter hypoxia in Upper Red Rock Lake over two study years with varying weather conditions; (2) further refining the location and duration of potential refugia from hypoxia; (3) 
developing a predictive model of environmental factors affecting under-ice DO; and (4) examining historical trends in climate-related hypoxia risk.

\section{Methods}

Study site

Upper Red Rock Lake (Fig. 1; 44 $36^{\prime} 41^{\prime \prime} \mathrm{N}, 111^{\circ} 43^{\prime}$ $36^{\prime \prime}$ ) lies at an elevation of $2017 \mathrm{~m}$ in the Centennial Valley in the Upper Missouri River Basin of southwest Montana. The 893 ha lake is surrounded by extensive wetlands and lies within Red Rock Lakes National
Wildlife Refuge. It is a cold, polymictic lake that rarely stratifies during the spring-to-fall seasons due to shallow depth and frequent wind mixing (Cutting et al., 2016). The lake is fed by five inlet tributaries (Fig. 1): two are reliant on snowmelt runoff from adjacent mountains (Red Rock and Tom creeks); two are spring-fed streams (Grayling, and East Shambow creeks); and one is a combination of upstream lake outlet and spring-fed discharge (Elk Springs Creek) (Gangloff, 1996). Flows exit the lake through a single outlet in the northwest corner of the lake that connects Upper Red Rock Lake to Lower Red Rock Lake and Red Rock River. Upper Red Rock Lake exhibits many characteristics typical of a winterkill-prone lake. The

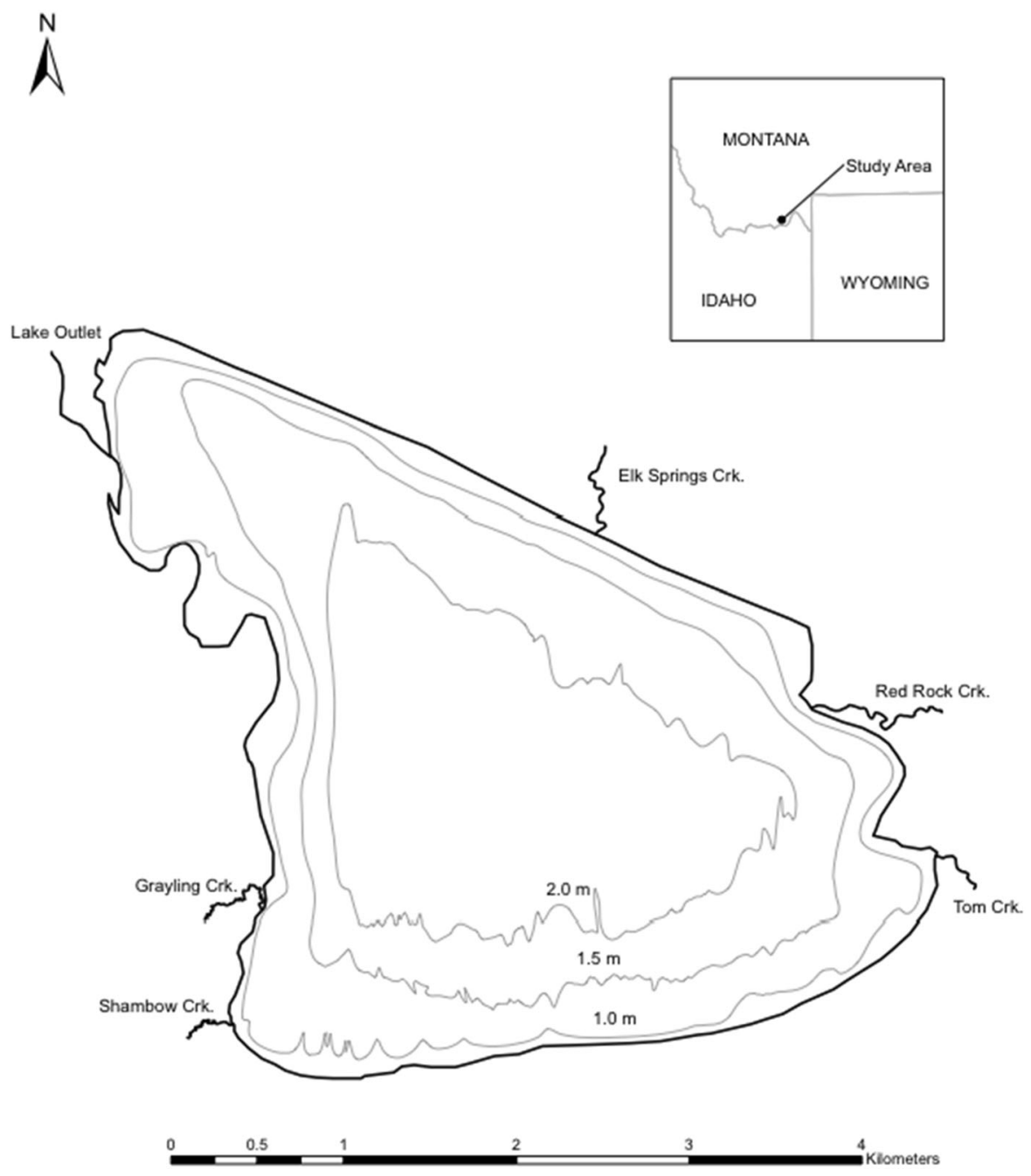

Fig. 1 Upper Red Rock Lake shown with smoothed bathymetric contours and location of inlet streams and lake outlet, Red Rock Lakes National Wildlife Refuge, Montana, USA 
lake experiences long winters, typically remaining icecovered from November to April. Depth is shallow and rather uniform, with a maximum depth of $2 \mathrm{~m}$ during the ice-free period. Abundant rooted macrophytes (Potamogeton spp., Elodea spp., Myriophyllum spp.) exist on a uniform bottom comprised of mud, peat, and detritus (Gangloff, 1996; Mogen, 1996). The lake supports a diverse fish assemblage, including Arctic Grayling, burbot (Lota lota), white sucker (Catostomus commersonii), longnose sucker (Catostomus catostomus), longnose dace (Rhinichthys cataractae), mottled sculpin (Cottus bairdi), brook trout (Salvelinus fontinalis), and cutthroat-rainbow trout hybrids (Oncorhynchus clarkii bouvieri $\times$ Oncorhynchus mykiss; Gangloff, 1996; Cutting et al., 2016).

\section{Lake sampling}

To assess the extent, duration, and annual variability in lake DO during winter, measurements were made every 2-4 weeks during the winters of 2013-2014 and 2014-2015 from before ice-up (October) until travel on lake ice became unsafe during spring ice breakup. This resulted in 14 sampling occasions spread across the two winters: 8 in 2013-2014 and 6 in 2014-2015. Fifteen sample sites were generated randomly for each sampling occasion using the Create Random Points tool in ArcGIS (ver. 10.2; ESRI, Redlands, CA) and included both lake (10 sites) and stream mouth (5 sites) habitat types. Sample size was determined by the maximum number of sites that could be reliably sampled in a day, given frequent severe winter conditions that posed a safety risk to the sampling crew. Sample locations were stratified to detect anticipated differences between DO concentration in the lake and in areas $\leq 300 \mathrm{~m}$ of stream mouths (Gangloff, 1996). Holes were drilled into the ice with a 10-cm-diameter hand auger at each sample location, and DO (mg/l) and water temperature measured at 1-meter intervals from the ice-water interface to the bottom using an electronic DO probe (YSI Professional Plus, Yellow Spring, $\mathrm{OH}$ ). Other possible covariates influencing under-ice DO that were also measured included ice thickness, snow depth, water depth, and air temperature. Air temperature data were obtained from a nearby weather station (Red Rock

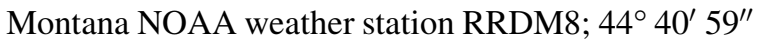
$\mathrm{N}, 111^{\circ} 49^{\prime} 59^{\prime \prime} \mathrm{W}$, elevation 2,039 m) located about
$12 \mathrm{~km}$ northwest and $22 \mathrm{~m}$ higher elevation than the lake.

Data analysis

At each sample site, DO and water temperature at 0,1 , and $2 \mathrm{~m}$ depth were averaged to generate mean values for each sample site. These values were then used to calculate lake-wide average DO concentration and water temperature by sampling occasion. Ice thickness and snow depth measurements from each sample site were used to calculate lake-wide averages in a similar manner. Variation in DO, water temperature, ice thickness, and snow depth across sampling occasions was assessed within years using a one-way ANOVA, followed by a Tukey-Kramer test to identify significant differences across sample dates. All statistical analyses were done with $R$ programming language ( $R$ Core Development Team, 2018). The strength of evidence was classified as significant at the $\alpha<0.05$ level.

To assess spatial variability in DO concentration in the lake, mean DO values for each sample site were calculated from measurements at $0 \mathrm{~m}$ and $1 \mathrm{~m}$ depth and input into ArcGIS. Only data from the upper $1 \mathrm{~m}$ of the water column were used as it was the only welloxygenated zone in the lake in both winters. The lower meter of the water column was consistently hypoxic (mean DO $<2.0 \mathrm{mg} / \mathrm{l}$ in 2013-2014, $<3.0 \mathrm{mg} / \mathrm{l}$ in 2014-2015) soon after complete ice cover. The upper meter, by contrast, was a comparatively dynamic layer, exhibiting a range of DO concentrations from $\sim 0$ to $10 \mathrm{mg} / \mathrm{l}$. DO concentrations $\leq 4 \mathrm{mg} / \mathrm{l}$ were considered hypoxic in this situation because these DO concentrations in this range elicited stress responses (behavioral avoidance and increased opercular beats) and decreased survival in juvenile and adult Arctic Grayling in laboratory experiments whereas such impairments were absent at higher DO levels (Davis et al., 2019).

Maps of spatial distribution of DO concentration in this upper $1 \mathrm{~m}$ surface layer were determined for each sampling occasion using the inverse distance weighted interpolation tool in ArcMap Spatial Analyst based on interpolated raster datasets of $20 \mathrm{~m} \times 20 \mathrm{~m}$ grid cells of DO concentration. Accuracy of predicted DO from spatial mapping was assessed by comparing predicted DO to an independent set of DO measurements conducted 1-2 days after initial sampling (10 sites 
per sample date) using linear regression. We found a strong association between predicted and actual DO values $\left(r^{2}=0.92, n=120 ; P<0.01\right)$, indicating that maps generated in ArcGIS provided good approximations of the spatial variation in DO present in the lake at each sampling occasion. Finally, we estimated the proportional volume of the hypoxic zone for each sampling occasion by calculating the proportion of the upper $1 \mathrm{~m}$ of the water column with $\mathrm{DO} \leq 4 \mathrm{mg} / \mathrm{l}$.

We used multiple linear regression to assess relationships between environmental variables and lake-wide average DO concentrations. For air temperature, we used maximum daily temperature (MDT) as the covariate, postulating that days with the lowest maximum temperature would produce the most severe winter conditions. Initial analysis revealed little evidence for multicollinearity among variables (Zuur et al., 2009). Model comparison was performed using Akaike's information criterion adjusted for small sample size (AICc; Burnham \& Anderson, 2002). We assessed relative model support by considering the variables included in the best-supported model, i.e., the model with the lowest $\mathrm{AIC}_{\mathrm{c}}$ score (Burnham \& Anderson, 2002), and by considering all models $<7$ $\mathrm{AIC}_{\mathrm{c}}$ units as plausible.

\section{Winter severity}

Based on the association between MDT below zero and low DO levels in the lake (see Results), we calculated an index of annual winter severity, and ostensibly the extent of winter hypoxia, by the number of days with MDT $\leq 0^{\circ} \mathrm{C}$ during ice cover (November to March) for each year of available air temperature data, spanning 28 years (1987 to 2015) from the Red Rock weather station. We then used linear regression to assess if the number of days with MDT $\leq 0^{\circ} \mathrm{C}$ has changed across this time span by assessing if the slope of the trend line was different from zero (Pederson et al., 2010; Isaak et al., 2012).

\section{Results}

Ice cover across the lake formed by November 15 , 2013 and November 25, 2014. Ice thickness increased to $\sim 0.5 \mathrm{~m}$ during both winters. The extent of ice cover was uniform across the lake except around intermittent, small openings $\left(<100 \mathrm{~m}^{2}\right)$ at the mouth of Elk Springs, Red Rock, Shambow, and Grayling creeks. Ice breakup began in the first week of April in 2014 and the last week of March in 2015. Ice cover was completely absent by mid-April of both years.

Lake-wide average DO concentration prior to ice formation in the fall was $9.0 \mathrm{mg} / \mathrm{l}$ and $10.2 \mathrm{mg} / \mathrm{l}$ in 2013 and 2014, respectively, and was uniform throughout the lake regardless of depth and site (Fig. 2). Within 40-50 d after the onset of lake ice, lake-wide average DO declined substantially to minimum levels of $4.3 \mathrm{mg} / \mathrm{l}(0.2 \mathrm{mg} / \mathrm{l}$ per day and $5.9 \mathrm{mg} /$ 1 (0.1 mg/l per day) during the winters of 2013-2014 and 2014-2015, respectively. After the sharp initial decline in DO following ice-over to the peak lows at midwinter, under-ice DO stabilized at low levels for 1 to 1.5 months, followed by a rapid increase to pre-ice levels by March 27, 2014 and February 16, 2015. During both years, DO rebound occurred when ice still completely covered the lake, approximately 2-4 weeks prior to ice breakup. During rebound, lake-wide average DO increased from 4.3 to $8.7 \mathrm{mg} / \mathrm{l}$ in 28 days in 2014 ( $0.2 \mathrm{mg} / \mathrm{l}$ per day), and from 5.9 to $9.8 \mathrm{mg} / \mathrm{l}$ in 14 days in 2015 (0.3 mg/l per day).

Despite a maximum water depth of only $2 \mathrm{~m}$, a significant DO and temperature gradient developed in the water column by midwinter during both years. In contrast to the sharp drop in lake-wide average DO, mean surface DO measured at the ice-water interface remained high during all sampling periods ( $6.5 \mathrm{mg} / \mathrm{l}, 2013-2014$; $8.0 \mathrm{mg} / \mathrm{l}, 2014-2015$ ), whereas DO decreased sharply with depth, with average DO at $1 \mathrm{~m}$ of $2.6 \mathrm{mg} / \mathrm{l}$ (2013-2014) and $5.1 \mathrm{mg} / 1$ (2014-2015), and with DO concentrations often anoxic in the lower hypolimnetic layer $>1 \mathrm{~m}$ deep (Fig. 3). The DO gradient persisted throughout the DO minima period, but ended when under-ice concentrations returned to an unstratified state by March 27, 2014 and February 16, 2015. A strong temperature gradient also developed during ice cover. For example, water temperatures at the ice-water interface ranged from 0.3 to $0.6^{\circ} \mathrm{C}$, whereas average lake bottom temperatures ranged from 3.6 to $3.7^{\circ} \mathrm{C}$ (Fig. 4).

Ice thickness increased over the course of both winters $(0.4 \mathrm{~cm} /$ day in $2013-2014$, and $0.2 \mathrm{~cm} /$ day in 2014-2015) but varied between study years. Maximum ice thickness was $\sim 43 \%$ greater in 2014 $(61.7 \mathrm{~cm})$ than in $2015(43.1 \mathrm{~cm})$ (Fig. 5) but was generally uniform across the lake at each sampling 
Fig. 2 Lake-wide average dissolved oxygen (DO) and water temperature $(95 \%$ confidence intervals), Upper Red Rock Lake, 2013-2014 (top panel) and 2014-2015 (bottom panel). DO and temperature values marked with different letters are statistically different (oneway ANOVA, $P<0.05$ )
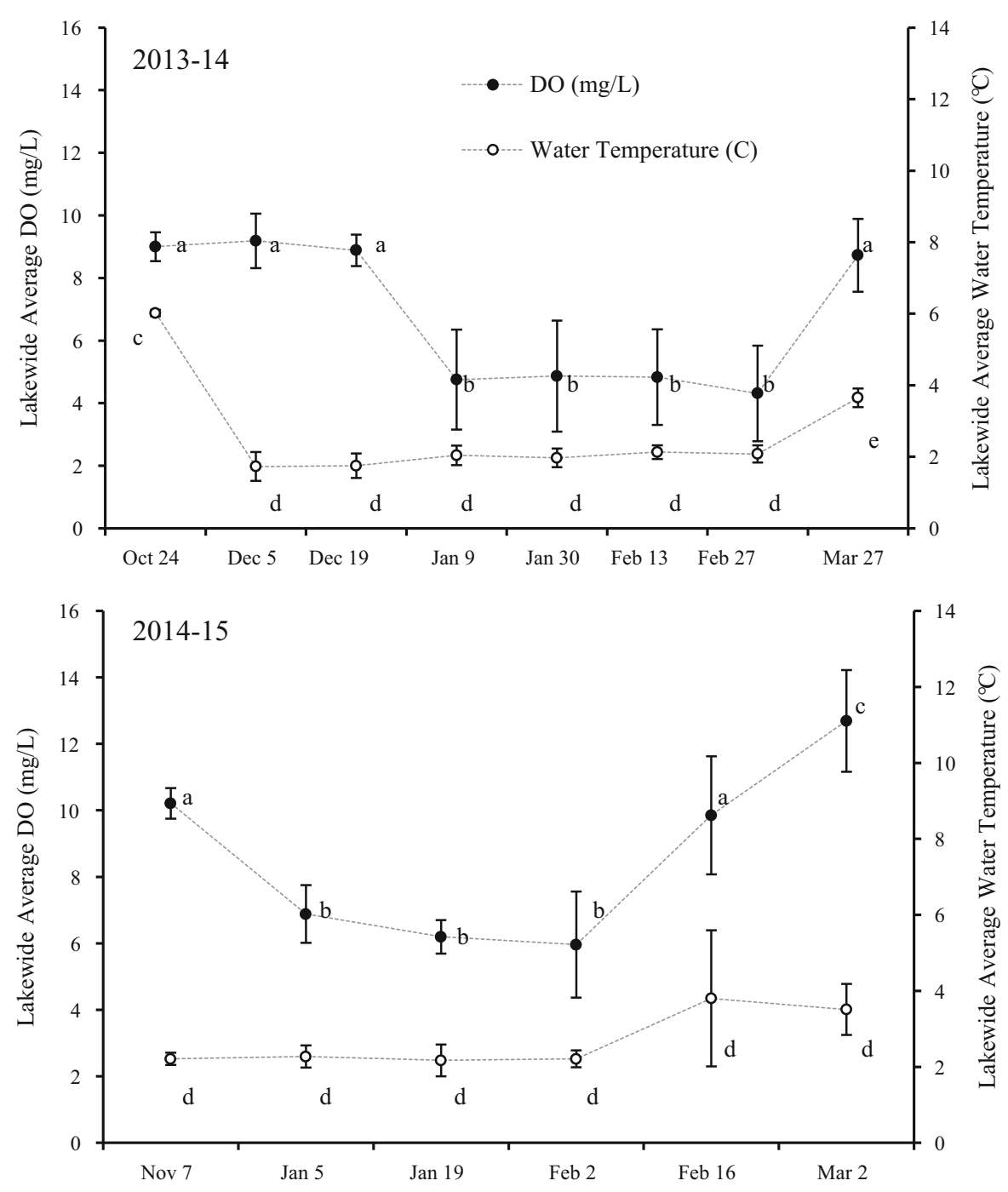

occasion (variation $<10 \mathrm{~cm}$ ). Similarly, maximum snow depth was nearly two-fold greater in 2014 $(18.1 \mathrm{~cm})$ than $2015(9.6 \mathrm{~cm})$. Snow depth, however, was variable across the lake due to wind scouring the ice surface (Fig. 5). Snow was largely absent from the ice surface by March 27, 2014, and by February 16, 2015.

DO interpolation maps showed the expansion and contraction of hypoxic areas as well as differences in DO concentration between the two study winters (Figs. 6, 7). Prior to, and shortly after, complete winter ice cover, the lake had uniformly high DO levels. During midwinter when DO reached minima levels, low DO areas were prevalent in the shallow northwest and southern parts of the lake, particularly in the lowest DO winter of 2013-2014. In contrast, areas near inlet streams remained well-oxygenated throughout the midwinter DO minima period. In 2014, the proportional volume of the hypoxic $(\leq 4 \mathrm{mg} / \mathrm{l})$ area in the upper $1 \mathrm{~m}$ expanded from $7 \%$ in early-January to $31 \%$ in late February, followed by a decline to $0 \%$ by the end of March. In contrast, the proportional volume of hypoxic area of the surface layer was $\sim 1 \%$ in 2014-2015, and normoxic DO levels ( $\geq 4 \mathrm{mg} / \mathrm{l})$ were present throughout the lake even in mid-February.

Lake-wide average DO over the two study years showed strong positive association with maximum daily air temperature MDT $\left(r^{2}=0.79, P<0.01\right)$, and a negative association with snow depth $\left(r^{2}=0.68\right.$, $P<0.01$ ) (Fig. 8). We found no association between 


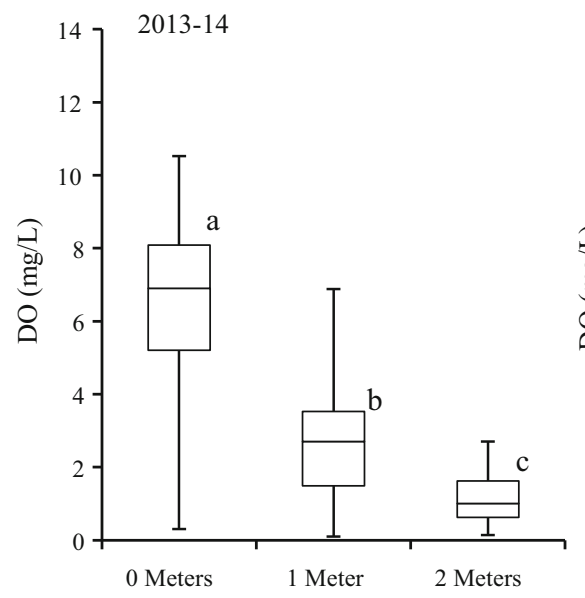

Fig. 3 Lake-wide average dissolved oxygen concentrations at 0,1 and 2 meters deep during the midwinter oxygen minima period, 2013-2014 (left panel) and 2014-2015 (right panel).

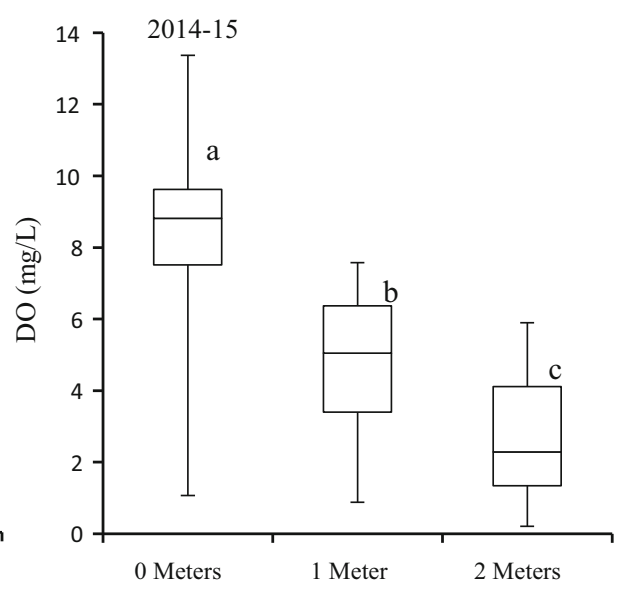

Horizontal bars in box plots indicate the minimum, 25th percentile, median, 75th percentile, and maximum values (oneway ANOVA, $P<0.05$ )
Fig. 4 Lake-wide average water temperature at 0,1 , and 2 meters deep during the midwinter oxygen minima period, Upper Red Rock Lake in 2013-2014 (left panel) and 2014-2015 (right panel). Horizontal bars in box plots indicate the minimum, 25th percentile, median, 75 th percentile, and maximum values (one-way ANOVA, $P<0.05$ )

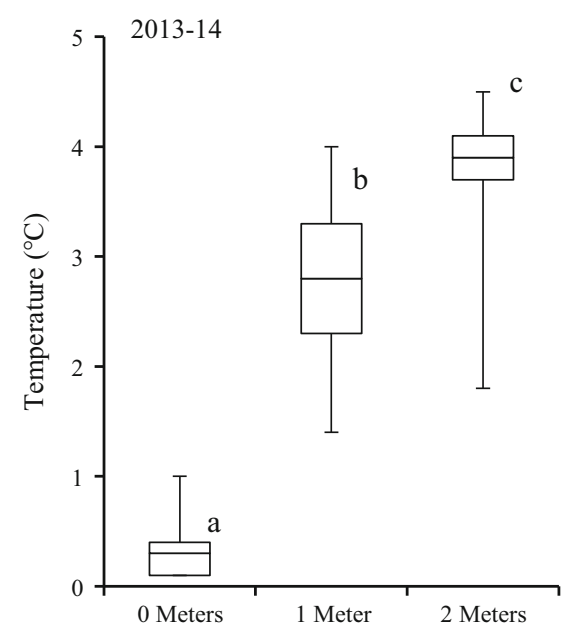

DO and either ice thickness $\left(r^{2}=0.26, P>0.05\right)$ or water temperature $\left(r^{2}=0.22, P>0.05\right)$. Model selection results indicated the model that contained maximum daily air temperature (MDT) alone best explained variation in average DO levels across the lake (Table 1). AIC rankings indicated that other models that included snow, ice, and water temperature also influenced average lake-wide DO levels, but to a lesser degree.

Plots of MDT and lake-wide average DO indicated that winter minima DO periods during both winters were closely associated with periods when MDT was $\leq 0^{\circ} \mathrm{C}$ (Fig. 9). Over the 28-year weather record, there was high variability in the number of days within a given year when MDT was $<0^{\circ} \mathrm{C}$, ranging from 62 to $103 \mathrm{~d}$ (mean $=81$ days; Fig. 10). Study winters, with relatively low and high DO levels, were above and below, respectively, the long-term average winter severity, with the winter of 2013-2014 having 23\% more days when $\mathrm{MDT} \leq 0^{\circ} \mathrm{C}$ than in 2014-2015 (2014: 88 days; 2015: 68 days). The plot of MDT days per year showed a declining but nonsignificant trend over the 28-year time period (Fig. 10; slope $=$ $-0.236, P=0.36$ ).

\section{Discussion}

Our study demonstrated pronounced spatial and temporal variation in DO availability during winter 
Fig. 5 Mean lake-wide average dissolved oxygen, ice surface snow depth, and ice thickness with $95 \%$ confidence intervals, 2013-2014 (top panel) and 2014-2015 (bottom panel)
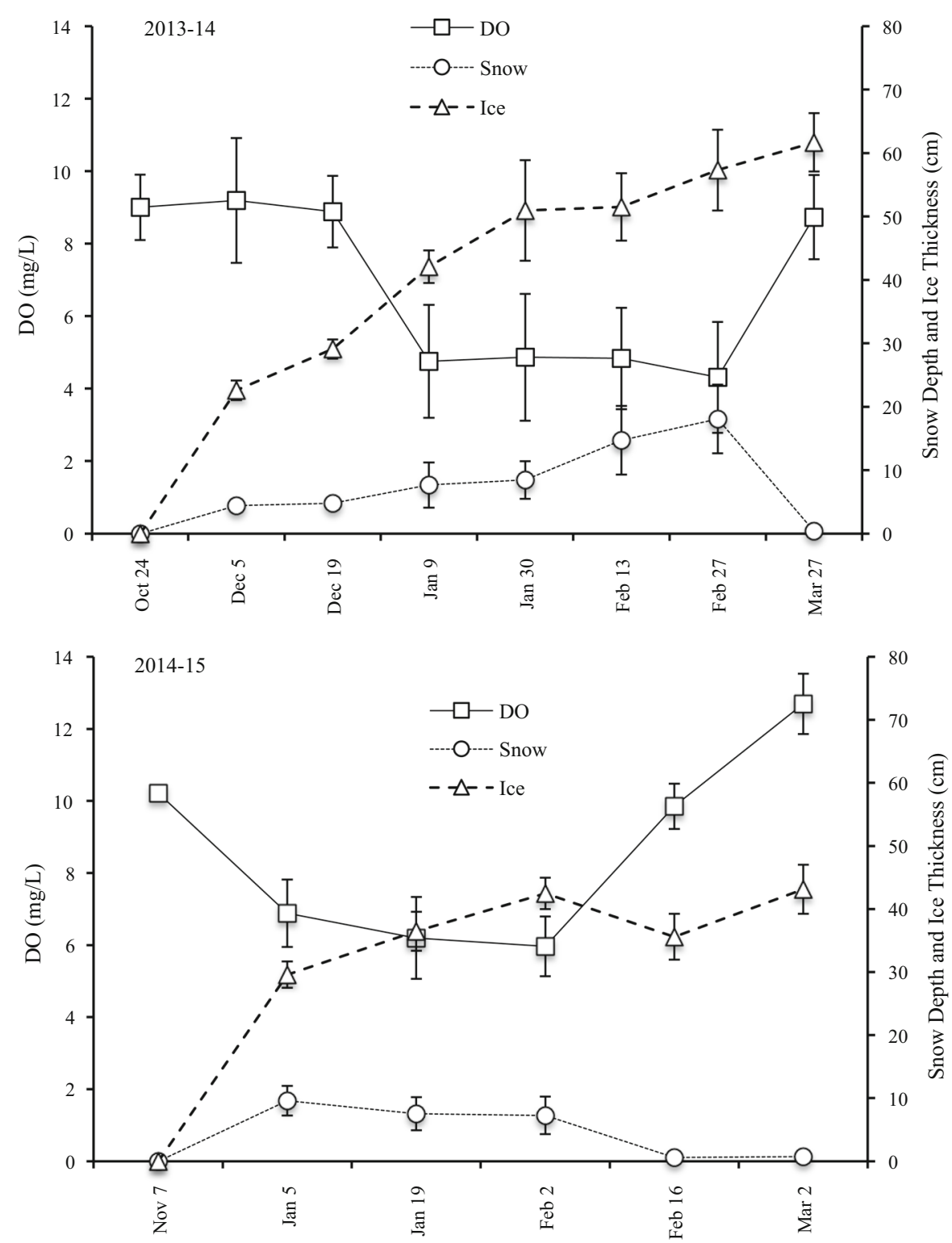

in a shallow, ice-covered lake. During midwinter, hypoxic DO concentrations were widespread, but some areas under the ice, particularly around stream mouths and immediately below the ice surface, remained well-oxygenated throughout the winter. This spatial variation in DO is not typically observed in studies of winter oxygen depletion and winterkill risk, which have generally utilized single point DO sampling to estimate extent of DO depletion in icecovered lakes (Barica \& Mathias, 1979; Babin \& Prepas, 1985; Prowse \& Stephenson, 1986; Leppi et al., 2016). However, the few studies that have employed more extensive DO sampling such as our study have similarly found evidence for high spatial variability in DO, even in small lakes prone to winterkill (Hasler et al., 2009), suggesting that such variability might be more widespread, especially in lakes with surface inflow (Gangloff, 1996; Guenther \& Hubert, 1991).

The extent of normoxic conditions in Upper Red Rock Lake in the winter was surprising as near-anoxic conditions had been measured in previous work and the lake has all the attributes common to lakes with high winterkill risk. We measured very low DO 

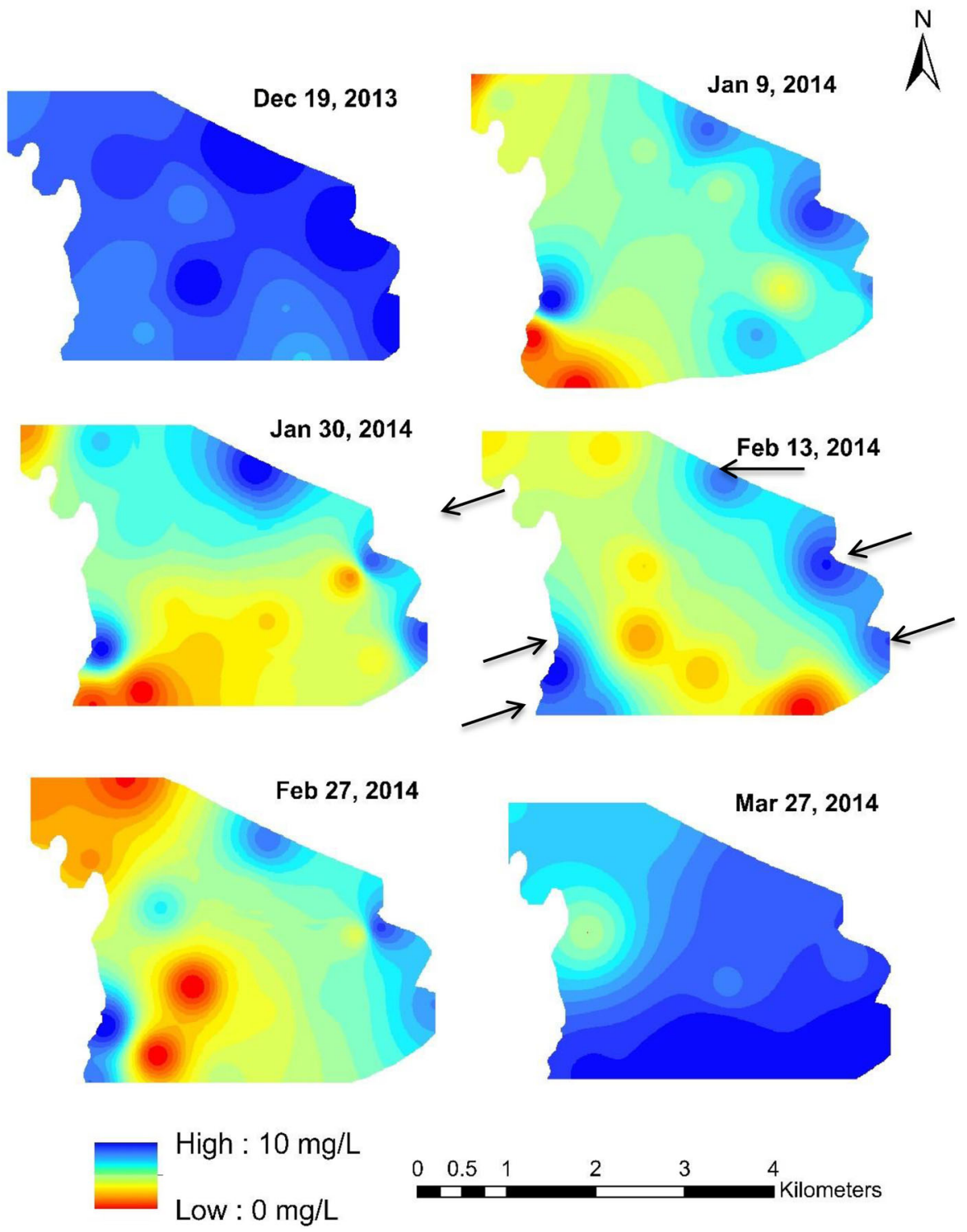

Fig. 6 Dissolved oxygen maps generated using inverse distance weighted interpolation in 2013-2014 on dates shown. Arrows on one map (February 13) show the location of the five inflowing and one outflowing tributaries

concentrations after ice formation for an extended period during both study winters, but most hypoxic conditions were observed at depths $>1 \mathrm{~m}$ deep. Extensive hypoxia in the hypolimnion in lakes has been observed in other studies (Mathias \& Barica, 1980; Prowse \& Stephenson, 1986; White et al., 2008; Leppi et al., 2016). We also observed hypoxia in the epilimnetic surface layer $<1 \mathrm{~m}$ below the ice surface, but its extent was much more variable than reported in most previous studies of winterkill-prone lakes.
Previous investigations of winterkill lakes reported relatively constant DO depletion rates once ice cover was achieved, allowing for prediction of winterkill based on measurements of lake volume and depletion rate (Barica \& Mathias, 1979; Prowse \& Stephenson, 1986; Leppi et al., 2016 but see Guenther \& Hubert 1991 for exception). Many of these studies relied on data from comparatively small lakes with little to no input of surface water from tributaries. In contrast, Upper Red Rock Lake had a distinctive non-linear DO depletion rate and considerable year-to-year variation. 

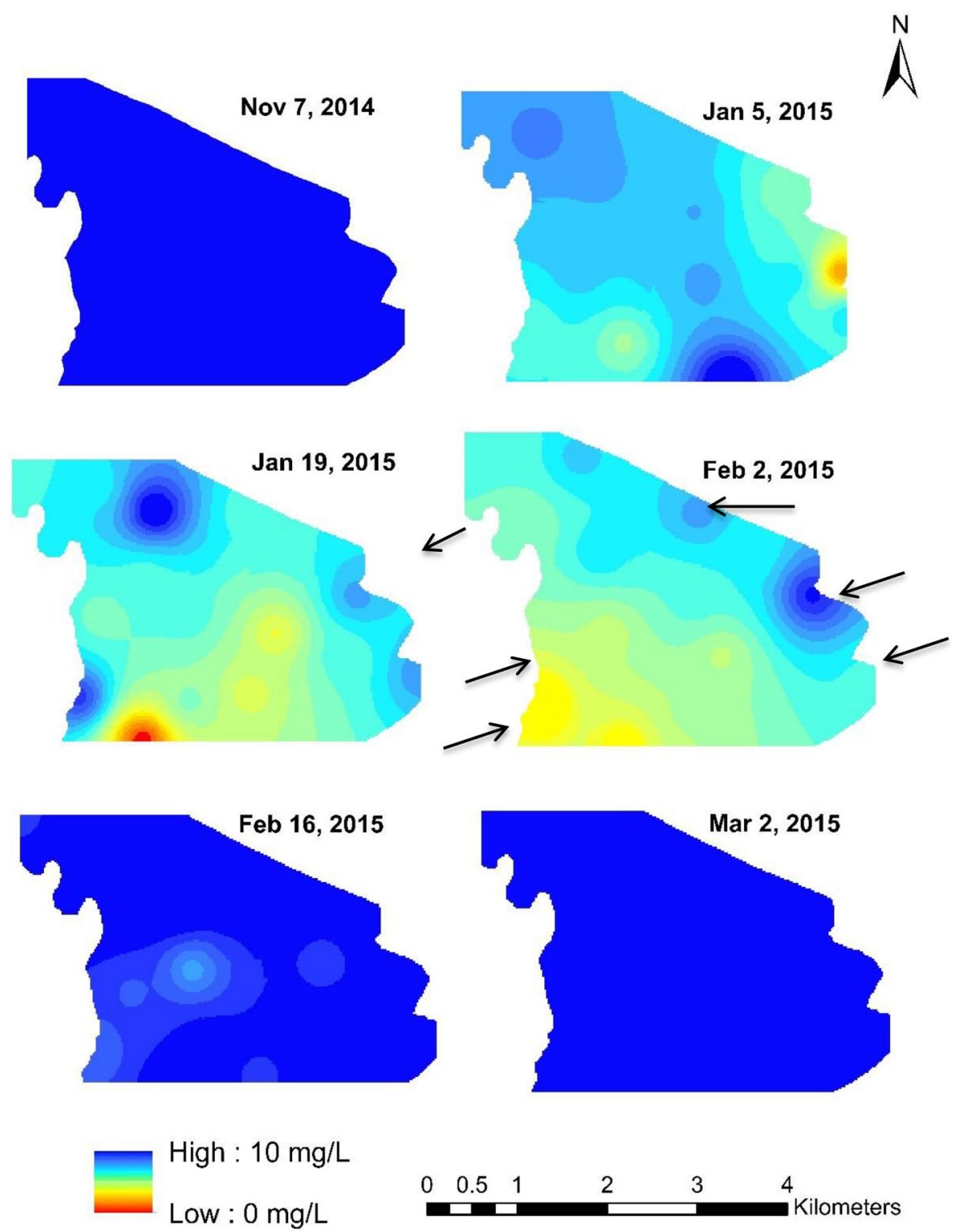

Fig. 7 Dissolved oxygen maps generated using inverse distance weighted interpolation in 2014-2015 on dates shown. Arrows on one map (February 2) show the location of the five inflowing and one outflowing tributaries

If the high DO depletion rate we observed in early winter had continued unchanged, average lake-wide DO concentrations would have reached $\sim 0 \mathrm{mg} / \mathrm{l}$ by early-February in 2014, and $\sim 4 \mathrm{mg} / \mathrm{l}$ by earlyMarch in 2015. Instead, the DO depletion rate leveled off by midwinter and remained stable until the rapid rebound in DO prior to ice-off during spring.

High variation in location and extent of hypoxia within the lake suggests an unidentified input of DO to the lake during the midwinter oxygen minima, preventing DO from being fully depleted. Plausible mechanisms of DO inputs during midwinter include: (1) input of oxygen-rich stream water, (2) photosynthetic production of oxygen by algae and submergent plants, and (3) oxygen input from springs located on the lake bottom. Our observations of intermittent ice cover on inlet streams and snow-free parts of the lake suggest mechanisms 1 and 2 could be responsible for DO inputs during the midwinter DO minima. Although mechanism 3 is possible, we did not find 
Fig. 8 Scatterplots of the relationship between lakewide average dissolved oxygen and maximum daily air temperature (A), lakewide average ice thickness (B), lake-wide average water temperature $(\mathbf{C})$, and lake-wide average snow depth (D)
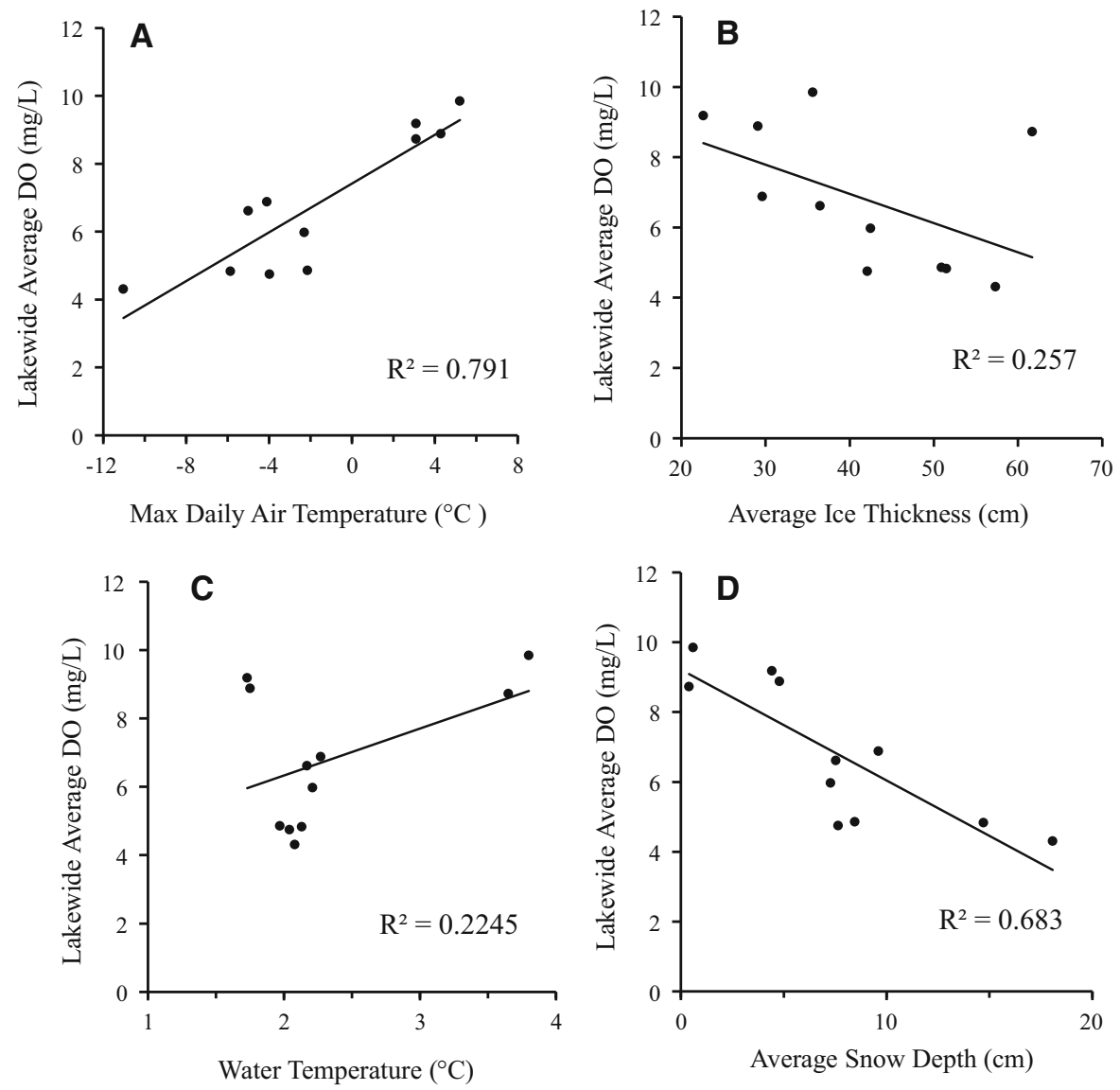

Table $1 \Delta$ AICc, $R^{2}$ and model coefficient estimates with 95\% confidence intervals for models of lake-wide average dissolved oxygen

\begin{tabular}{|c|c|c|c|c|c|c|}
\hline Model & $\Delta \mathrm{AICc}$ & $R^{2}$ & $\beta_{1}, \mathrm{MDT}$ & $\beta_{2}$, snow & $\beta_{3}$, Ice & $\beta_{4}$, water temp \\
\hline$\beta_{O}+\beta_{I} \mathrm{MDT}$ & 0.00 & 0.80 & $0.35(0.22-0.50)$ & & & \\
\hline$\beta_{0}+\beta_{2}$ snow & 4.56 & 0.68 & & $\begin{array}{l}-0.32(-0.48 \text { to } \\
-0.15)\end{array}$ & & \\
\hline$\beta_{0}+\beta_{1} \mathrm{MDT}+\beta_{2}$ snow & 5.19 & 0.79 & $\begin{array}{l}0.33(-0.04 \text { to } \\
0.71)\end{array}$ & $\begin{array}{l}-0.03(-0.38 \text { to } \\
0.33)\end{array}$ & & \\
\hline$\beta_{0}+\beta_{1} \mathrm{MDT}+\beta_{3}$ ice & 3.87 & 0.82 & $0.33(0.18-0.49)$ & & $\begin{array}{l}0.03(-0.09 \text { to } \\
0.03)\end{array}$ & \\
\hline$\beta_{0}+\beta_{1} \mathrm{MDT}+\beta_{4}$ water temp & 4.53 & 0.80 & $0.34(0.18-0.50)$ & & & $\begin{array}{l}0.36(-0.79 \text { to } \\
1.52)\end{array}$ \\
\hline $\begin{array}{l}\beta_{0}+\beta_{1} \mathrm{MDT}+\beta_{3} \text { Ice }+\beta_{4} \\
\text { water temp }\end{array}$ & 6.35 & 0.88 & $0.24(0.06-0.41)$ & & $\begin{array}{l}0.06(-0.13 \text { to } \\
0.00)\end{array}$ & $\begin{array}{l}1.02(-0.20 \text { to } \\
2.25)\end{array}$ \\
\hline
\end{tabular}

MDT refers to maximum daily air temperature

evidence of spring sources such as areas of open water or unusual temperature or oxygen plumes along the lake bottom. The second mechanism is also plausible, especially during times in winters with low to no snowpack where photosynthesis by aquatic plants and algae can still occur under the ice (Oveisy et al., 2014). 
Fig. 9 Maximum daily air temperature (dashed gray line) and lake-wide average dissolved oxygen (DO) concentration (open circles) at Upper Red Rock Lake during winter 2013-2014 and 2014-2015, showing the midwinter DO minima period corresponded to periods with MDT $\leq 0^{\circ} \mathrm{C}$
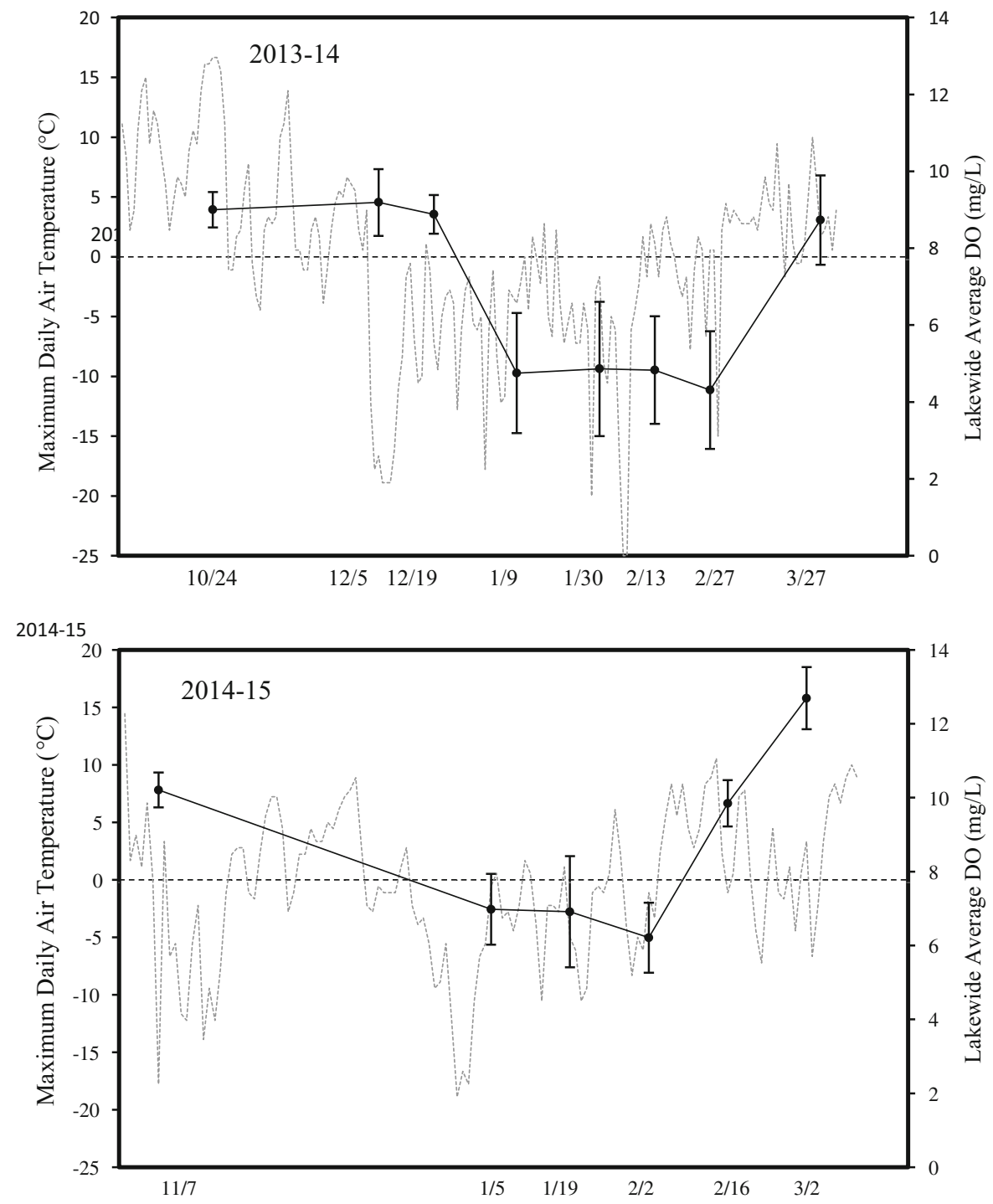

Notably, we found a negative association between lake-wide DO and snow depth, supporting this hypothesis. Previous videography surveys identified green aquatic plants persisting and photosynthesizing throughout the winter months under the ice during a year of low snow cover (Gangloff, 1996). We believe that mechanism 1 is the most important driver of DO dynamics, as Gangloff (1996) and our study found high DO at inlet stream mouths, suggesting that streams delivered DO-rich water throughout the winter months. We hypothesize that the lower density and temperature of these inflowing tributaries would have allowed this oxygen-rich water to spread out along the ice-water interface without mixing with bottom layers (Bergmann \& Welch, 1985). Guenther and Hubert (1991) also found that winter hypoxia was less pronounced in lakes with surface inflow.

Another unexpected result of our study was the lake-wide spring DO rebound prior to ice loss (Baehr \& DeGrandpre, 2002; White et al., 2008). The typical pattern of lake re-oxygenation in winterkill lakes is DO rebound concomitant with reconnection with the atmosphere during spring ice breakup (Barica \& Mathias, 1979). However, we observed rapid reoxygenation at least 2-4 weeks prior to ice breakup when ice cover was still complete. We hypothesize that increased flows due to valley floor snowmelt along with resumption of photosynthetic activity with 


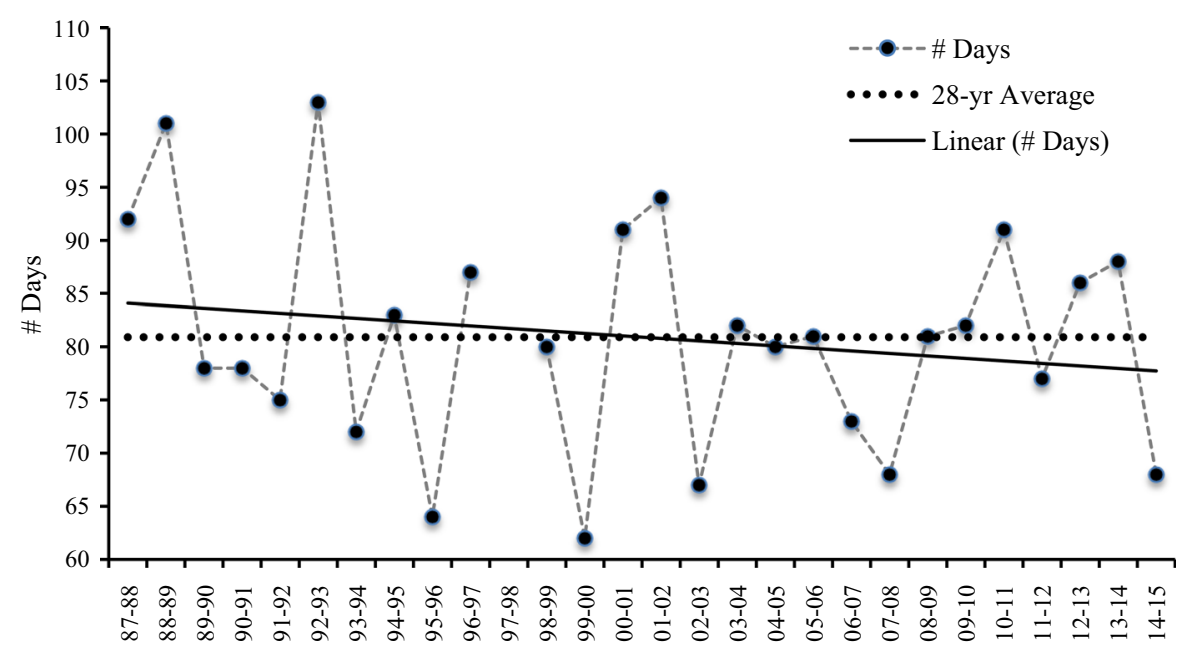

Fig. 10 Total number of days with maximum daily air temperature $\leq 0^{\circ} \mathrm{C}$ for the months November to March for the winters of 1987-1988 to 2014-2015 (dashed line), including the 28-year average number of days with maximum daily air

increased light penetration due to dwindling snow depths on the lake ice, influenced the rebound in lakewide DO levels during maximum ice extent in earlyspring. Such rebound has not been documented elsewhere to our knowledge and is an important consideration for estimating duration of winterkill risk.

Our results also suggest that variation in maximum daily air temperature is a potentially useful surrogate for estimating the extent and degree of winter hypoxia. Measurements of winter DO levels in two other winters of quite different severity in Upper Red Rock Lake by Gangloff (1996) provide additional support of this relationship. In the winter 1994-1995, DO was at low levels $(<0.5 \mathrm{mg} / \mathrm{l})$ at lake sampling sites excluding tributary mouths throughout the winter and the number of MDT days below zero was above average (83 days); in contrast, winter DO was much higher throughout the lake the following winter $(>6 \mathrm{mg} / \mathrm{l})$ and number of MDT days below zero $(n=64)$ was well below average. If MDT days below zero is representative of winter severity and winter hypoxia as these data suggest, the weather record data and DO measurements among different years indicate a high degree of interannual variability in the threat of hypoxia. Future climate projections indicate less frequent and less severe hypoxic conditions in shallow, ice-covered lakes with warming temperatures during winter (Fang \& Stefan, 2000). However, we temperature $\leq 0^{\circ} \mathrm{C}$ (81 days, solid line), and regression trend line of the average number of days with maximum daily air temperature $\leq 0^{\circ} \mathrm{C}$ over the 28-year period (dash-dot line; slope $-0.236, P=0.36$ )

found only a slight negative decline in winter severity over a 28-year period. Upper Red Rock Lake occurs in a mountain valley with frequent temperature inversions in winter that result in persistent cold temperatures. We suspect that such inversions may buffer some of the effects of rising regional temperatures (Pederson et al., 2010).

Our findings have important implications for measuring the dynamics of winter hypoxia and estimating its impacts on overwintering fishes. In Upper Red Rock Lake, the inlet tributary mouths likely offer DO refugia key for survival of grayling and other species during winters with otherwise widespread hypoxic conditions (Gangloff, 1996; Davis et al., 2019). Identification of such refugia will help conserve these critical habitats (Weber et al., 2013; Tibbles et al., 2018). The approach we used in our study provides a useful framework for quantifying and mapping the seasonal dynamics of the extent and severity of winter hypoxia, and for identifying critical winter habitats in other systems.

In our study, we show evidence of substantial variation in development of hypoxia both within and among years, emphasizing the need for better understanding of the processes that affect hypoxia over space and time. Better defining the relative role of inlet streams versus in situ photosynthesis on driving midwinter DO levels and re-oxygenation prior to 
ice-off would be particularly fruitful areas for further research.

Acknowledgements The study was funded from generous contributions from Montana Department of Fish, Wildlife and Parks, the US Fish and Wildlife Service, National Wildlife Refuge System and Ecological Services Program, and the Friends of Red Rock Lakes National Wildlife Refuge. We thank the following people for their technical advice or help with field investigations under challenging conditions: Jon Rees, David Dockery, Leif Halvorson, Luke Holmquist, Lucas Bateman, Rob Clark, Tracy Elam, Glenn Boltz, Charlotte Marshall, Paige Maskill, Jasmine Cutter, Cody Deane, Emma Freeman, and Nikki Diedrich. We gratefully acknowledge the staff of the Red Rock Lakes National Wildlife Refuge, particularly Bill West, for logistical support. Molly Webb and Wyatt Cross provided comments on earlier drafts of the manuscript.

Open Access This article is licensed under a Creative Commons Attribution 4.0 International License, which permits use, sharing, adaptation, distribution and reproduction in any medium or format, as long as you give appropriate credit to the original author(s) and the source, provide a link to the Creative Commons licence, and indicate if changes were made. The images or other third party material in this article are included in the article's Creative Commons licence, unless indicated otherwise in a credit line to the material. If material is not included in the article's Creative Commons licence and your intended use is not permitted by statutory regulation or exceeds the permitted use, you will need to obtain permission directly from the copyright holder. To view a copy of this licence, visit http://creativecommons.org/licenses/by/4.0/.

Funding Funding was provided by Montana Fish, Wildlife, and Parks (Grant Number 4W4357) and US Fish and Wildlife Service (Grant Number 4W4549).

\section{References}

Agbeti, M. D. \& J. P. Smol, 1995. Winter limnology: a comparison of physical, chemical and biological characteristics in two temperate lakes during ice cover. Hydrobiologia 304: 221-234.

Babin, J. \& E. E. Prepas, 1985. Modelling winter oxygen depletion rates in ice-covered temperate zone lakes in Canada. Canadian Journal of Fisheries and Aquatic Sciences 42: 239-249.

Baehr, M. M. \& M. D. DeGrandpre, 2002. Under-ice $\mathrm{CO}_{2}$ and $\mathrm{O}_{2}$ variability in a freshwater lake. Biogeochemistry 61: 95-113.

Barica, J. \& J. A. Mathias, 1979. Oxygen depletion and winterkill risk in small prairie lakes under extended ice cover. Journal of the Fisheries Research Board of Canada 36: 980-986.

Barica, J., J. Gibson \& W. Howard, 1983. Feasibility of snow clearing to improve dissolved oxygen conditions in a winterkill lake. Canadian Journal of Fisheries and Aquatic Sciences 40: 1526-1531.

Bergmann, M. A. \& H. E. Welch, 1985. Spring meltwater mixing in small arctic lakes. Canadian Journal of Fisheries and Aquatic Sciences 42: 1789-1798.

Burnham, K. P. \& D. R. Anderson, 2002. Model Selection and Multimodel Inference: A Practical Information-Theoretic Approach. Springer, New York.

Cooper, G. P. \& G. N. Washburn, 1949. Relation of dissolved oxygen to winter mortality of fish in Michigan lakes. Transactions of the American Fisheries Society 76: 23-33.

Cutting, K. A., W. F. Cross, M. L. Anderson \& E. G. Reese, 2016. Seasonal change in trophic niche of adfluvial Arctic Grayling (Thymallus arcticus) and coexisting fishes in a high-elevation lake system. PLoS ONE 11(5): e0156187.

Danylchuk, A. J. \& W. M. Tonn, 2003. Natural disturbances and fish: local and regional influences on winterkill of fathead minnows in boreal lakes. Transactions of the American Fisheries Society 132: 289-298.

Davis, M. N., T. E. McMahon, M. A. H. Webb, J. E. Ilgen, A. T. Hitch, M. E. Jaeger \& K. A. Cutting, 2019. Winter survival, habitat use, and hypoxia tolerance of Montana Arctic Grayling in a winterkill-prone lake. Transactions of the American Fisheries Society 148: 843-856.

Fang, X. \& H. G. Stefan, 2000. Projected climate change effects on winterkill in shallow lakes in the northern United States. Environmental Management 25: 291-304.

Gangloff, M. M, 1996. Winter habitat and distribution of Arctic Grayling in Upper Red Rock Lake, Red Rock Lakes National Wildlife Refuge, Montana. Master's thesis. Montana State University, Bozeman, Montana.

Greenbank, J., 1945. Limnological conditions in ice-covered lakes, especially as related to winter-kill of fish. Ecological Monographs 15: 343-392.

Guenther, P. M. \& W. A. Hubert, 1991. Factors influencing dissolved oxygen concentrations during winter in small Wyoming reservoirs. Great Basin Naturalist 51: 282-285.

Hasler, C. T., C. D. Suski, C. D. Hanson, S. J. Cooke \& B. L. Tuft, 2009. The influence of dissolved oxygen on winter habitat selection by largemouth bass: an integration of field biotelemetry studies and laboratory experiments. Physiological and Biochemical Zoology 82: 143-152.

Hughes, G. M., 1973. Respiratory responses to hypoxia in fish. American Zoologist 13: 475-489.

Isaak, D. J., S. Wollrab, D. Horan \& G. Chandler, 2012. Climate change effects on stream and river temperatures across the northwest U.S. from 1980-2009 and implications for salmonid fishes. Climatic Change 113: 499-524.

Kaya, C. M., 1992. Review of the decline and status of fluvial Arctic Grayling, Thymallus arcticus. Montana. Proceedings of the Montana Academy of Sciences 1992: 43-70.

Leppi, J. C., C. D. Arp \& M. S. Whitman, 2016. Predicting late winter dissolved oxygen levels in Arctic lakes using morphology and landscape metrics. Environmental Management 57: 463-473.

Liknes, G. A. \& W. R. Gould, 1987. The distribution, habitat and population characteristics of fluvial Arctic Grayling (Thymallus arcticus) in Montana. Northwest Science 61: 122-129.

Malm, J., L. Bengtsson, A. Terzhevik, P. Boyarinov, A. Glinsky, N. Palshin \& M. Petrov, 1998. Field study on currents in a 
shallow, ice-covered lake. Limnology and Oceanography 43: $1669-1679$.

Mathias, J. A. \& J. Barica, 1980. Factors controlling oxygen depletion in ice-covered lakes. Canadian Journal of Fisheries and Aquatic Sciences 37: 185-194.

Mogen, J. T, 1996. Status and biology of the spawning population of Red Rock Lakes Arctic Grayling. Master's thesis. Montana State University, Bozeman, Montana.

Nelson, P. H., 1954. Life history and management of the American Grayling (Thymallus signifer tricolor) in Montana. Journal of Wildlife Management 18: 324-342.

Oveisy, A., Y. R. Rao, L. F. Leon \& S. A. Bocaniov, 2014. Three-dimensional winter modeling and the effects of ice cover on hydrodynamics, thermal structure and water quality in Lake Erie. Journal of Great Lakes Research 40: 19-28.

Pederson, G. T., L. J. Graumlich, D. B. Fagre, T. Kipfer \& C. C. Muhlfeld, 2010. A century of climate and ecosystem change in Western Montana: what do temperature trends portend? Climatic Change 98: 133-154.

Peterson, D. P. \& W. R. Ardren, 2009. Ancestry, population structure, and conservation genetics of Arctic grayling (Thymallus arcticus) in the upper Missouri River, USA. Canadian Journal of Fisheries and Aquatic Sciences 66: 1758-1774.

Prowse, T. D. \& R. L. Stephenson, 1986. The relationship between winter lake cover, radiation receipts and the oxygen deficit in temperate lakes. Atmosphere-Ocean 24: 386-403.

R Core Development Team, 2018. R: A Language and Environment for Statistical Computing. R Foundation for Statistical Computing, Vienna, Austria. http://www.R-project. org/.

Rens, E. \& J. Magee, 2007. Montana Arctic Grayling annual monitoring report, 2006. Submitted to: Fluvial Arctic Grayling Workgroup. Montana Fish, Wildlife and Parks, Bozeman.

Terzhevik, A., S. Golosov, N. Palshin, A. Mitrokhov, R. Zdorovennov, G. Zdorovennova \& I. Zverev, 2009. Some features of the thermal and dissolved oxygen structure in boreal, shallow ice-covered Lake Vendyurskoe, Russia. Aquatic Ecology 43: 617-627.
Tibbles, M., J. A. Falke, A. R. Mahoney, M. D. Robards \& A. C. Seitz, 2018. An interferometric synthetic aperture radar (InSAR) habitat suitability model to identify overwinter conditions for coregonine whitefishes in Arctic lagoons. Transactions of the American Fisheries Society 147: 1167-1178.

Tonn, W. M. \& J. J. Magnuson, 1982. Patterns in the species composition and richness of fish assemblages in northern Wisconsin lakes. Ecology 63: 1149-1166.

Vincent, R. E, 1962. Biogeographical and ecological factors contributing to the decline of Arctic Grayling, Thymallus arcticus Pallas. Michigan and Montana. Doctoral dissertation. University of Michigan, Ann Arbor, Michigan.

Warren, J. M. \& M. Jaeger, 2017. Centennial Valley Arctic Grayling adaptive management plan. Red Rock Lakes National Wildlife Refuge and Montana Fish, Wildlife, and Parks Report, Lima, Montana.

Warren, J., M. Jaeger, A. Gilham, K. Cutting, L. Bateman, T. Paterson \& M. Duncan, 2020. Centennial Valley Arctic Grayling Adaptive Management Project Annual Report, 2019. Red Rock Lakes National Wildlife Refuge and Montana Fish, Wildlife, and Parks Report, Lima, Montana

Weber, C., C. Nilsson, L. Lind, K. T. Alfredsen \& L. E. Polvi, 2013. Winter disturbances and riverine fish in temperate and cold regions. BioScience 63: 199-210.

Welch, H. E. \& J. Kalff, 1974. Benthic photosynthesis and respiration in Char Lake. Journal of the Fisheries Board of Canada 31: 609-620.

White, D. M., H. M. Clilverd, A. C. Tidwell, L. Little, M. R. Lilly, M. Chambers \& D. Reichardt, 2008. A tool for modeling the winter oxygen depletion rate in arctic lakes. Journal of the American Water Resources Association 44: 293-304.

Zuur, A. F., E. N. Ieno, N. J. Walker, A. A. Saveliev \& G. M. Smith, 2009. Mixed effects models and extensions in ecology with R. Springer, New York.

Publisher's Note Springer Nature remains neutral with regard to jurisdictional claims in published maps and institutional affiliations. 